\title{
Heidegger on Rhetoric: An Existential Deconstruction of the Notion of Communication
}

\author{
Deepak Pandiaraj ${ }^{*}$
}

\section{Abstract}

Martin Heidegger's phenomenological interpretation of Aristotle's theory of rhetoric can be interpreted to understand the existential dimension of communication. Taking Heidegger's 1924 Marburg lecture, Being and Time and other texts dealing with the problem of the being of language as theoretical sources, this paper presents the importance of Heidegger's conception of rhetoric and analyses the ontological aspects of communication as such. Taking the understanding of being-in-the-world and speaking-with-one-another, further, it is argued that if rhetoric is a way of having the existential view about how matters present themselves in a particular manner by virtue of speaking about it with-one-another, then it is in the region of the doxa of people. A case study of rhetorical analysis of the film Blow-Up is used to explain the process of existential communication.

Keywords: Existential Communication, Rhetoric, Heidegger, Language, Doxa

\section{Introduction}

Martin Heidegger's notion of rhetoric can be read as a conception of existential communication that explicates the ontological

* Indian Institute of Technology - Bombay, Powai, Mumbai, Maharashtra, India; deepak.pandiaraj@gmail.com 
dimension of communication. It is important to raise the question of communication afresh to consider all its interweaving onticontological aspects. I argue in this paper that Heidegger's notion of rhetoric in his 1924 interpretation of Aristotle's Rhetoric offers that possibility. Heidegger's rhetorical understanding of communication dwells on our everyday experience of communication to show that every ontic communicative expression comes out of more primordial disclosure of the world; it lays bare how the existential constituting structure of communication namely logos, pathos and ethos come together ecstatically disclosing the world in a meaningful way for human beings in their basic mode of existence, Being-in-the world speaking with-one-another.

This paper has three sections after the introduction; the first section is to provide the necessary context by presenting the importance of Heidegger's unique appropriation of the classical notion of rhetoric from Aristotle; the next section focuses on the details of Heidegger's existential reading of rhetoric within Dasien's structure of disclosure, the concealed ontological dimension of everyday communication that which makes every ontic communication possible. The last section deals with the demonstration of this existential communication through an analysis of the film, Blow up. Finally, I present the conclusion based on the film analysis, the place of doxa in the framework of rhetoric. Though logos discloses the world, only rhetoric makes the re-disclosure possible.

\section{Situating Heidegger's Rhetoric Lecture}

In this section I present the notion of existential communication, using Heidegger's early work that deals with language, communication, and rhetoric, directly or indirectly. I find Being and Time (BT; 1927) and the 1924 lecture course Basic Concepts of Aristotelian Philosophy (BCAP) relevant for the current task. Though I use other works of Heidegger, these two texts figure in a major way as they are influenced by Heidegger's existential appropriation of Aristotle's Rhetoric.

Discourse as communication is a broader conception that takes into consideration the ontological dimension of Dasein by virtue of its relation to Being. All communication, whether reductively assertive 
and propositional or thoughtfully disclosive, is embedded in the interweaving ontic-ontological dimensions. But when the disclosive nature of logos, the ontological dimension of Dasein's relation to language, is brought to articulation in the act of communication attentively, there is a qualitative difference in the very experience of communication for all those taking part in this process. One can say that in communication when it happens in this manner, the speaker and the listener cease to be ontologically separate as in the case of reductive propositional communication. This mode of communication that lets the discourse gather and present the existential possibility, which is concealed otherwise when the very occurrence of communication happens, depends on the quality of participation of the communicator, the receiver and the subject matter. Such an examination of possible modes of discourse is discussed in Heidegger's reading of Aristotle's Rhetoric and this creative interpretation is more accessibly presented in BCAP. It emphasises that the focus of rhetorical matter should be the interpretation of the being-there of human beings with regard to the basic possibility of speaking-with-one-another. It is possible to formulate discourse as existential communication based on his notion of discourse in BT as well as by going back to BCAP as one can see clearly there that the existential dimension of discourse emerges in Heidegger's encounter with Aristotle's Rhetoric. He writes in BCAP that 'the גóyos [logos], which has this function of exhibiting, has the character of a definite communicating. I communicate with others; I have the world there with the other and the other has the world there with me, insofar as we talk something through - Kouvwvia [koinonia] of the world. Speaking is, in itself, communicating; and, as communication, it is nothing other than Kouvwvia' (Heidegger, 2009, p. 43). Even when one is communicating in the everyday mode, there needs to be a shared world among those participating. 'Shared world' here means a community of people with a history and language, sharing a common ethos.

However, Aristotle's own definition of rhetoric speaks about it in terms of persuasive techniques as the following passage from the Rhetoric shows: 
Rhetoric may be defined as the faculty of observing in any given case the available means of persuasion...the power of observing the means of persuasion on almost any subject presented to us; and that is why we say that, in its technical character, it is not concerned with any special or definite class of subjects (Aristotle, 1984, p.4624).

Unlike Plato, one can see that there is a positive understanding of rhetoric in Aristotle as techniques of persuasive speaking for creating or changing the perception about something in a definite way in those individuals who listen to it. Aristotle's Rhetoric would seem like a manual for the speaker to choose the right means of persuasion in a particular temporal context. However, Heidegger brought out a phenomenological understanding in the Rhetoric by focusing on what is unsaid in the text. Heidegger's interpretation has challenged the traditional place of rhetoric within Aristotle's works and most effectively affected the relationship of rhetoric to philosophy (Gross, 2017, p. 512).

Heidegger's philosophical research relates to his discontent with the then existing philosophy of language and its formal approach to the question of meaning: how meaning arises out of the interaction between language and human beings. In fact, Heidegger did take Aristotle's treatment of pathos as presented in the second book of Rhetoric seriously. He took it beyond the psychological framework of subjective internal experience and formulated it as the ground from which logos emerges. Concepts like ready-to-hand, being-with, world and Dasein are extended and modified versions of Aristotle's oikos, koinonia/polis, ethos and praxis (Buren, 1994, pp. 226-228). The most important pillars of Being and Time, the existential structures of disclosedness, attunement, understanding, and discourse, are an appropriation of pathos, techne and phronesis, and logos and hermenia in Aristotle (Buren, 1994, p. 228). Daniel Gross observes that the concept of rhetoric operating in Heidegger's lecture is so broad that he defines it as "the study of how a human being is in the world through language" (2017, p. 511).

Heidegger's existential appropriation of Aristotle's rhetoric is a significant contribution to the question of meaning in the everyday context in comparison with the researches in the philosophy of 
language. One cannot ignore the important developments in analytical philosophy in dealing with the question of meaning in everyday context, which are more sophisticated theories than Aristotle's in the Rhetoric. J. L. Austin's speech acts theory is one such development. He came up with conditions of successful speech act in the name of felicity conditions for 'happy' functioning. Accordingly, speech acts do not have truth values but the success of such acts can be evaluated as appropriate or inappropriate. Austin, in How to Do Things with Words (1962), listed six conditionsi, failing to meet which will result in 'unhappy' consequences that he calls as cases of misfires and abuses. While Austin's theory is a step beyond propositional content and certainly such a pragmatic notion of speech as the action is a further development in the philosophy of language, I want to point out that such an approach is still caught up in the traditional presumptions about the essence of human being and language.

Heidegger's original notion of language and meaning allowed him to appropriate the idea of rhetoric through his interpretation of Aristotle that rhetoric is not just about communicating techniques to stir and manipulate people, trading on their emotions with least commitment to truth. Heidegger's effort to revisit Aristotle's Rhetoric in a lively way through his lecture for his students was significant. In fact, Gadamer once recounted his experience that it was as though seeing Aristotle alive as a contemporary thinker in the presentation of Heidegger when he attended the lecture as Heidegger's student (Gross, 2017, p. 519). It has also influenced many students of Heidegger like Hanna Arendt, Helene Weiss, Walter Brocker, and Ernst Tgendhat whose contributions to Aristotelian scholarship is noteworthy (Buren, 1994, p. 226). Such a task of reinterpreting Aristotle's basic concepts opened up new possibilities in philosophizing (Marassi, 1986, p. 96). Gadamer viewed Heidegger as an 'Aristotelian redivivus', due to his kairological appropriation of Aristotle's basic concepts in a phenomenological way (Buren, 1994, p. 226). Heidegger acknowledges the importance of rhetoric in Being and Time (1962) in this way:

contrary to the traditional orientation, according to which rhetoric is conceived as the kind of thing we 
'learn in school', this work of Aristotle must be taken as the first systematic hermeneutic of the everydayness of Being with one another. (p. 178)

It is not only Aristotle's Rhetoric that gets revived but Heidegger did place Aristotle's ethics into the ontological horizon of the concept of Kinesis in the Physics, Metaphysics, De anima and De motuanimalium (Buren, 1994, p. 230). In the next section, we will first see in more detail Heidegger's appropriation of Aristotle's concept of rhetoric and its connection to the lifeworld, and then discuss more on the details of the constitutive structure of rhetoric in relation to Dasein's existential structure and mode of being-inthe world.

\section{Heidegger's Reading of Aristotle's Rhetoric}

According to Heidegger, Being-in in the sense of Being-in-theworld is equiprimordial with Being-with other human beings. So Being-in-the-world-with-one-another is the basic mode of Dasein's existence and so the question of political existence is fundamental to Heidegger. In his Being and Truth lecture (1933-34), during which period he was involved in political activities, he asks the question: what it means to be a people. In his attempt to answer the question, Heidegger (2010) clarifies the notion of being-with-one-another:

This with-one-another cannot be understood as based on the fact that there are many human beings whom one must keep in order; instead, we belong with one another to the state, we exist on the basis of the state. And this existence

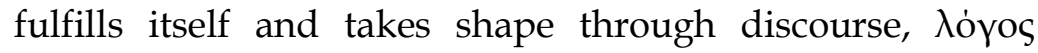
[logos]. The science that is concerned with the ability to talk, rhetoric, is the fundamental science of human beings, the political science. (p. 123)

It is also possible to see rhetoric as an act of ethical performance as Aristotle treats it as an effort to attain a fitting response from an audience in a particular moment about something that matters to them. Indeed, rhetoric, as opposed to sophistry, is a better model of communicative ethics and Calvin Schrag in his book, Communicative Praxis and the Space of Subjectivity (1986), describes how rhetoric and ethics meet in the space of ethos through the 
Greek concept of kathokonta (fitting response) (Schrag, 1986, p. 202). Schrag writes: "the fitting response is thus enjoined to do double duty-to preserve the tradition, without which communication could not proceed, and to critique the tradition in search of a pharmakon [emphasis added] that might remedy its conceptual and existential ills" (Schrag, 1986, p. 207). Discourse in its everydayness gives rise to either genuine discourse (in the mode of the disclosure of phenomena that matter to humans) or idle talk (in the mode of the phenomena that appear superficially), and thus discourse when guided by rhetoric can become such a pharmakon or therapeutic remedy.

While rhetoric lends itself for wrong purposes too, the concrete situation in which the needs of people calling for a response is an opportunity for a phronetic engagement with right deliberation and judgement to guide people towards what is good at that given situation for them (Hyde, 1994, p. 382). Any speaker who is attuned to the temporal moment in which one finds oneself along with other listeners brings to view for all to see the 'articulation of actuality by means of possibility' (Marshall, 2017, p. 59). David Marshall (2017) notes that these kinds of performances are not to be thought in terms of special skills but as performances emerging from habituation and repetition:

If we wish to appropriate Heideggerian concepts for the purposes of rhetorical analysis, our focus should be everydayness - as a capacity to begin again (and again), as a modal category with which to organize our sense of the appearing of the world, and as an account of how that which is present shades absent. (p. 69)

It is important to note here that the nature of practical comportment is always open-ended and never reaches completion as perfection, be it use of techne or phronesis.

If one accepts Thomas Sheehan's understanding of Being that it is nothing but the meaningful presence of things and the world to human beings, then this ontological dimension of being-there in a meaningful way is the primordial way in which we encounter our world (Heidegger, 2009, p. 203). According to Thomas Sheehan 
what disclosedness of things to Dasein involve are, "(1) the relative stability and constancy of the meaningful thing (währen); (2) the locus of its meaningful appearance, namely the world of human concerns (-vor-); and (3) a certain movement into appearance, a thing's being brought from an undisclosed but potential intelligibility into an actually operative one (in die Unverborgenheit)" (Sheehan, 2014, p. 252). Disclosedness happens as a result of being-with the other and the world is given to someone by virtue of being a part of the speech community, culture and its ethos; in short, it is out of the passively accepted doxa that we make sense of things. The how of being-with-one-another is an ontological-existential condition out of which the ontic everyday communication is made possible and, after all, rhetoric performances are deliberate amplifications of mundane interactions and discussions among people. This pragmatic comportment of the know-how of being in the concrete moment is not a special art but arises out of what is given to Dasein as the primordial understanding of being in its ordinary life. In fact, Allen Scult would go on to argue that it is the dynamics of rhetoric that let us choose to act out of the given set of language possibilities that shape our world. It even includes the possibility of philosophy: The locus of "the 'how' of the being of philosophy is located within the "how' of the being of rhetoric" (Scult, 1999, p. 150). Any context of rupture or unexpected crisis is the context for the new possibility of understanding the inconspicuous existential structures operating in everydayness.

Heidegger discusses in Being and Time how the unexpected breakdown in the everyday activities due to the failure of equipment exposes them in a new light; i.e. as the transition from the ready-to-hand to the present-at-hand mode of engagement. Theodore Kisiel thinks that the political crisis in Germany in the 1930s opened up for Heidegger new possibilities of seeing the ontological operations that were concealed prior to this historical moment. Kisiel (2000) writes: “Aristotle's Rhetoric is for Heidegger accordingly a hermeneutics of everydayness in crisis, of being with one another in an everydayness that has been radically disturbed and thus exposed, in its structures, for ready ontological examination" (p. 201). As existential possibilities unfold in a particular crisis situation, it calls for responses and thus sometimes the world speaks to itself and Dasein may or may not listen to the 
voice of being. This existential dimension of disclosedness in the mode of being-in-the-world-along-with-others in this kind of unexpected rupture in the normal routine needs articulation in a manner that resonates with the ethos of the people. This new sprout of understanding can be made sense of positively only if it comes out of the tradition even if the sprout is against the common doxa; i.e., that which also can be otherwise. Kisiel demonstrates that Heidegger's existential appropriation of Aristotle's Rhetoric brings together the core elements pathos, ethos and logos as always already present in any speech situation, and parallels the three disclosive structural moments of Dasein correspondingly: disposition, understanding and discourse (Kisiel, 2000, p. 201).

If Dasein is existentially never closed, then its relation to its world in moments of crisis should be seen as an opportunity for authentic resolve; being open and listening to the silent call of conscience is an option only if one is receptive to being's communicationacknowledging the nullity, thereby embracing the finitude of human life. Such an experience manifests in the articulation of the saying of being. At such moments, existence communicates to Dasein in a passive way in order for it to appropriate the meaning of existence actively. Such response of Dasein to the call of Being de facto shows that Being indeed needs human beings for it to articulate the rupture/exposure/disclosure of the world in the explicit discourse of Dasein. Stuart Elden recognises the logos as the highest possibility of human being within the mode of being-withone-another. Within this sphere of existential communication, the difference between speaking and listening is not useful except in an analytical sense. Elden (2005) argues that "Logos is a possibility of human being, which brings it to the highest possibility of its being, the euzen. But this is no longer mere logos, but dialektos, speaking with others, hermeneia, moving toward an understanding with others. Speaking is therefore at one with the mode of hearing, listening"(p. 288). Dasein is a kind of being that is existentially driven by non-being in sync with the future orientation of its temporal structure of care. Sheehan explains this: "imperfect being engenders an imperfect locus of meaning: the world as the dynamictransitive realm of mediation" (Sheehan, 2005, p. 206). Thus, Dasein in its everyday concern exists as speaking-with others (negotiating, discussing, struggling) on the basis of its existential structure, 
which is always oriented towards the not yet realised existential possibilities, primordially given in one's thrownness, which in turn determines their concrete meaning in the present moment in terms of the ontic concerns of one's self along with others and the world.

The rhetorical approach to communication amplifies the inherent possibilities that lie within the structure of communication and in effect, it moves the listeners as well as lets the phenomenon of interest manifest as it is. What are its conditions of possibility? If communication rhetorically understood is logos that performs its function appropriately with respect to the ethos and pathos of the listeners, communication is possible when its constitutive elements are present in a balanced way in coherence with the doxa, mood and the subject matter of the listening people. According to my reading of Heidegger's conception of 'rhetoric', the existential interpretation of it presents 'rhetoric' with its fundamental connection to doxa and mood; it is in doxa that anything is shown initially. Pathos is the ground condition of logos. Heidegger (2009) writes the following in his discussion about the connection of pathos to logos:

Insofar as גóyos [logos] is taken as speaking-with-oneanother, which has the function of working out the interpretation of being-there in its everydayness. Insofar as the חá $\theta n$ [pathē]are not merely an annex of psychical processes, but are rather the ground out of which speaking arises, and which what is expressed grows back into, the ná $\theta$ n [pathe]], for their part, are the basic possibilities in which beingthere itself is primarily oriented toward itself, finds itself. ( $p$. 176)

It is established that epistemic inquiry begins by doubting commonsense. It aims for universal knowledge, whereas rhetoric begins and ends in doxa within the sphere of the ethos of a speech community with an aim to genuinely present the phenomenon to the listener in its concrete attuned being-there. Succinctly

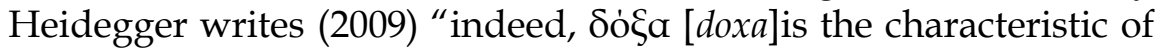
trust in that which shows itself initially. And that which shows itself initially is the basis of the investigation of the matter itself" (Heidegger, 2009, p. 103). He notices the inner connection of logos to doxa:

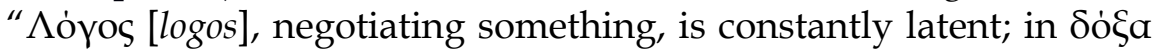


[doxa], bringing-to-language is constantly on the alert. $\Delta$ ó $\xi a[$ doxa] is precisely that from which speaking-with-one-another arises, by which it is motivated; and, at the same time, it is also that with which it negotiates" (Heidegger, 2009, p. 102). He also points out

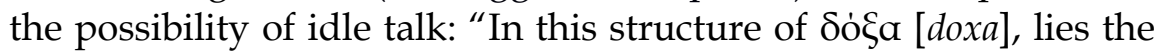
possibility of its reaching a characteristic authority and stubbornness" (Heidegger, 2009, p. 102). Therefore, one can see that the locus of existential communication in the shared world is in the doxa. The region of rhetoric, therefore, is ethos as any rhetorical performance will work with it, of it and ultimately also modify it. It is similar to the very function of philosophy as a possibility that comes out of the ordinary common conversation and also challenges the commonsense when new critical possibilities emerge with reason.

Having seen the fundamental relation of doxa to rhetoric, it is clear that rhetoric in this sense goes beyond the reduced notion of being a technique in the business of persuasion. The border understanding of rhetoric can be appreciated only when it is experienced or illustrated in its concrete everyday life experience. So, I am presenting my analysis of the film Blow-Up, in the following section to show how rhetoric operates in a photographer's day. It is an attempt to demonstrate how phronetic communicative performance like any artistic creation such as music takes all possible and available means in the given concrete context to achieve its telos (Buren, 1994, p. 234).

\section{A Rhetorical Analysis of Blow-Up}

Michelangelo Antonioni's Blow-Up shows the lifeworld of a young photographer (David Hemmings) in the 1960s in a way that can help us see how rhetoric works in terms of its possibilities. Every communicative context is rhetorical but only sometimes the genuinely open possibilities of the rhetorical context may come to the fore. The way Hemmings relates to people and things around indicates the nature of his relation to his world. As a modern photographer in London, he is involved in his work; he clicks a variety of photos that reflect different shades of the city such as violence, homelessness and peace for a photo-documentary. He takes photos of a young model (Veruschka) as if he possesses her by demanding of her certain kinds of poses. The way he takes 
control of her with his camera clearly shows that he knows what exactly he wants from her. He loses his temper during a photo shoot when the models do not fit themselves according to his imagination about how they should move and maintain themselves. His understanding of his right as a photographer is above the considerations of the feelings of his subjects. His arrogant disposition towards women subjects can be made sense of better if it is juxtaposed with the discourse of modern scientific knowledge, founded on the certainty of truth because Hemmings understands the legitimacy of the medium of photography in terms of its power to capture the truth. His interactions with the models and also with two teenage girls who beg him for a chance to pose clearly depicts the position of women as subjects to be represented in his world. At one point in the film the photographer after listening to the conversation with an artist named Bill (John Castle) about the experience of spontaneity in bringing the abstract expressions out in the form of painting, responds with a question, "can I buy it?" Bill, in turn, says "No" to Hemmings, signifying his lack of receptivity at that moment in the conversation as well as in his artistic relation to things. ${ }^{\text {ii }}$

In the course of the day, when Hemmings visits an antique shop, an old man almost chases him away as if he knows that the young man does not know how to value things from the past. While waiting for the shop owner to while away time and ward off his boredom he starts clicking pictures. As he is clicking, he walks into a public park where he takes some random pictures of landscape, nature, birds, and unexpectedly encounters a couple at a distance in the silent ambience. Hemmings immediately snaps photos of a mysterious woman (Vanessa Redgrave) with a man in his business suit, who seems to be older than her (Ronan O'Casey). Upon noticing this, the young woman comes running towards him to tell him to stop taking pictures. She seemed to be in a state of terror and she pleaded him to give her the film without any success. Not only he refused her plea but continued to take pictures as she was moving away from him till she disappeared. Then he goes back to the antique shop and manages to buy an old propeller, which he finds attractive. But the way he handles and perceives the propeller reflects his tendency to immediately possess things that he finds attractive without really understanding anything about them. 
Just after the purchase Hemmings meets Ron for whom he works. He discusses with Ron about those pictures for the photodocumentary and mentions that he has taken a fabulous picture in the park. And he suggests to Ron that what he clicked in the park could be placed as the final photo to end the documentary on peace as the earlier photos portrayed violent and miserable aspects of the city. The pictures taken according to him at that moment gave him pleasant feelings as they appeared to him as the beautiful mysterious women, the feeling of love, and the green landscape with birds and so on. Then he goes back to the studio to find that Vanessa Redgrave desperately wanted to retrieve the film before it is developed. He didn't expect her so soon just after she confronted him for the film in the park. In her attempts to seduce him in order to steal the film she fails. But she seems to be attracted to him and gives in to his play only to get deceived by him as he intentionally gives her the wrong film roll. When he starts developing the pictures in the real roll, he begins to find something enigmatic in the photos. The photos no more evoke pleasant feelings when he figures something enigmatic in the gaze of the mysterious women in one of the pictures. Like the way a detective works, he further takes the direction of the gaze as a clue to solve this enigma by zooming in that area where the gaze was pointing to. He concludes finally that she was looking at someone holding a gun hiding in the bush. It is interesting to note that this part of the movie goes on without any music to emphasise the real, silent enigmatic call. The director for some reason never gives any name to the main characters, the arrogant photographer, and the mysterious woman, in the movie. At some point when the photographer asks her name or phone number, she writes her phone number. Having figured out the truth about the attempted murder, Hemmings immediately dials the phone number that she gave to him only to realise that she deceived him giving a wrong number. This is when he begins to feel something more enigmatic and he calls Ron immediately. He shares with Ron about his feelings related to the photos in the park until it gets interrupted by those teen 'birds' waiting to be photographed. I quote the words he utters to Ron to show that he is unable to make sense of his feelings: "Something fantastic's happened. Those photographs in the park, fantastic! Somebody was trying to kill somebody else. I saved his life." 
Hemming's self-understanding as a photographer is disturbed by the series of enigmatic events unfolding. He is no more in control of things and people as he used to be. Instead, everything is elusive and he is being moved by things and people around him. This unusual feeling is probably difficult to face and so he invites the distraction happily by letting the teen girls into the studio. He does not take pictures of them but he is playing with them. Suddenly he sends them off as if he finds something enigmatic in one of those hanging pictures. It is the photo of a long shot of the mysterious young girl running away from him in the park just before she disappeared. When he observes it in different shades of lighting and magnifies that suspicious section of the photograph, he resolves finally that what he sees might be a dead body lying on the ground. This time again another layer of the same event captured in the park reveals something that shocked him. Immediately he leaves the studio to the park a second time but without his camera. Only when he nears the dead body did he realise that his habituated hands could not reach the camera. He realises that he does not have what gives him so much power when he needed it most, the camera. He wants to click pictures of the dead body but he cannot. Feeling helpless he goes back to his home to witness Bill making love with his wife, Patrica (Sarah Miles). His voyeuristic desire keeps his eyes stuck. Apparently, Patrica enjoys it and requests him not to leave as she is reaching the peak of pleasure. Then he returns to his studio to find all pictures developed and the negative missing except for one picture. That one picture is the only evidence he is left with which is coarse due to low resolution and high magnification. Patricia comments on the only evidence when she comes there to meet him and he explains what happened: "it looks like one of Bill's paintings". It just means that he cannot now be sure of anything he thinks about what happened in the park and the only picture left is so abstract that it can be interpreted any way.

Hemmings rushes immediately to meet wherever Ron is and, on the way, he spots the girl in the park. Before he stops the car and gets down to the spot, she is missing. He goes in search of her but in vain and enters a music concert. What happens in there has something to tell us about his destabilised world. When the guitarist smashes his guitar and throws it to the audience, there 
was chaos. It happens all of a sudden that the audience turns into a crazy mob, and everyone is trying to get hold of the broken guitar. He goes wild, stirred by the event happening there, and finally manages to get the neck of the guitar. As soon as he escapes out of the frenzied mob, he just stares at them, discards it on the floor, and heads to Ron's place. This just shows that while he is sure of what he wants from others as a photographer, he is not sure of his own world. Just like he wanted to buy one of Bill's paintings, he brought the propeller instinctually. When he was asked about the purpose of the propeller, he has no deep feelings or reason for it but he says, "nothing, it is beautiful". Probably his words indicate that deep inside him he is homeless and his job as the photographer is really inauthentic insofar as the meaning of life comes from that profession. He did express his dissatisfaction with his work in his earlier meeting with Ron and that he wanted to be free. But then he has nothing to say about what kind of freedom he is searching when Ron provokes him on that. This enigmatic feeling that resists any articulation in understanding and expression in language is shown brilliantly in the movie through other characters too. Even the antique shop owner does not know what she wants but she is sure that she does not enjoy running the antique shop. Patrica is unhappy with her marriage but she is not sure what to do. This existential dimension of 'nothingness' communicates to Hemmings in the way things and people are elusive, but he distracts himself with all kinds of tasks that are familiar to him as the master.

Continuing the story, he reaches the place where Ron is enjoying the party with Veruschka and others. While he tries to get Ron's attention, he sees Veruschka and remembers that she is supposed to be in Paris. When he expressed it to her, she replies that she is in Paris. He then continues to convince Ron that it is really important to take a shot of the corpse lying in the park. Ron who is disoriented does not share his urgency and did not find any sense in what he says. So, Ron in response says: "I am not a photographer" and in turn asks him "What did you see in that park?" His answer to that question is "Nothing" indicating that there is no point in persuading Ron.

Hemmings sleeps there that night and as soon as he wakes up the next day, he visits the park in hurry with his camera to get the shot 
of the dead body. It turns out that this time he has the camera but what he wants to capture as evidence has disappeared again. He hits the camera signifying his ultimate giving up of his efforts to secure the 'truth' that his camera/eyes witnessed. Nothing more to hold on as he walks holding the camera without showing any inveterate manifestation of the photographer as we know him through the movie. Probably for the first time he does not use his camera to capture something and he realises that he is actually in the grip of something enigmatic. When he accepts the 'nothingness' and co-responds to what is there open in the world, he watches the tennis mime performed by the same group of merrymakers. There is neither ball nor racket with them but there is a game that unfolds before his eyes. He did not distract himself or immediately take pictures; instead, he participates in the game by responding to its disclosure. When everyone turned towards the direction of the ball that crossed over the fence and one of the players expresses through her embodied speech that he is expected to retrieve the ball, he runs and tosses the ball back. Now he even hears the sound of the ball hitting the racket pointing to the fact that he is really free now. He now knows that truth just like art discloses itself in the way it wants and one can only be open to it in order to know it but can never master it. He comes to terms with himself and the situation as he listens to what life existentially communicates.

Thus, Being speaks rhetorically in the horizon of multiple possibilities and only those who are open to the rhetoric of life, art, can 'be' free. What it means 'to be' in the true sense as far as human beings are concerned is to be free in this sense. Finally, Blow-Up comes to an end, revealing the essence of the communication of Being: Being speaks to us in the way it presents or re-presents the world by concealing itself. The photographer himself disappears at the end of the movie emphasising that Being is Being when it lingers in its appearances and vanishes in time for the manifestation of other possibilities.

\section{Conclusion}

Rhetoric, as understood by Heidegger, recognises the primordial truth at work in communication (truth as aletheia or unconcealment/disclosure) as the fundamental way humans relate 
with their world; in other words, disclosive communication. Dasein as being-in-the world is always already in communication primordially with its world as Being discloses itself through language. Dasein's moods or dispositions (pathos) disclose the passive way in which the world affects humans; that is their thrownness. Dasein's projection (ethos) of its possibilities in terms of its self-understanding based on the interpretation and understanding of its place in society is another existential feature that keeps it always ahead of itself; that is, its projective understanding. These two existential aspects of Dasein-thrown projection-are equiprimordial and they are articulated in discourse (Logos) that gathers all that is and makes them present in its appearances (and re-apperances). Human beings exist in their everydayness with average intelligibility or doxa, the existential primordial view through its attuned understanding by virtue the discourse/language that posses them.

The importance of rhetorical performances, to which pertains our common use of the word 'rhetoric', lies in the possibility of seeing how the subject matter presents itself in the basic mode of human beings speaking with one another. It amplifies these existential elements that operate in the everyday mode of existence, which existentially communicate and thus either maintain or modify the doxa-that which is responsible for the meaningfulness of things/world, self and others. The film analysis demonstrates that the rhetorical notion of communication does not privilege the ontological dimension as if it determines ontic expression in ontic language just like one-way traffic, but it shows how the ontological coincides with ontic material expressions. This rhetorical way of understanding ontological dimension of communication brings out how the actuality changes the existential possibilities of the photographer is disclosed: David Hemings' experience of the world as a photographer in the 1960s London, whereby everything around him including people become objects of his photographic representation, finally reaches its limit as a particular unanticipated experience opens up to him new ways of seeing the world. Thus, when one co-responds to the rhetoric of Being by heeding the enigmatic silent call, our world is disclosed differently nevertheless in the form of authentic meaningful renewed doxa. 


\section{Acknowledgement}

I would like to thank Prof. Siby K. George, IIT Bombay for his valuable guidance and encouragement in bringing out this research work, without which this paper would not have seen the light of the day.

\section{References}

Aristotle. (1984). The complete works of Aristotle (Vol. I\&II). (J. Barnes, Ed.) Princeton, N.J: Princeton University Press.

Austin, J. (1994). How to do things with words. London: Oxford University Press.

Buren, J. V. (1994) . Aristotle. In J. V. Buren, The young Heidegger (pp. 220234). Bloomington: Indiana University Press.

Elden, S. (2005). Reading Logos as speech: Heidegger, Aristotle and rhetorical politics. Philosophy \& Rhetoric, 38(4), 281-301. Retrieved from https://doi.org/10.1353/par.2006.0001

Gross, D. M. (2017). Heidegger's 1924 Lecture course on Aristotle's Rhetoric: key research implications. 50(4), 509-527. doi:10.5325/philrhet.50.4.0509.

Heidegger, M. (1962). Being and time. (J. M. Robinson, Trans.) Oxford, UK: Blackwell Publishers Ltd.

Heidegger, M. (2009). Basic concepts of Aristotelian philosophy. (R. D. Tanzer, Trans.) Bloomington: Indiana University Press .

Heidegger, M. (2010). Being and truth. (G. F. Polt, Trans.) Bloomington: Indiana University Press.

Hyde, M. J. (1994). The call of conscience: Heidegger and the question of rhetoric. Philosophy \& Rhetoric, 27(4), 374-96. Retrieved from http://www.jstor.org/stable/40237822

Kisiel, T. (2000). Situating rhetorical politics in Heidegger's protopractical ontology 1923-25: The French occupy the Ruhr. International Journal of Philosophical Studies, 8(2), 185-208. doi:10.1080/09672550050084009

Kompridis, N. (2014). Working enigma: receiving Antonioni's Blowup(Abstract). The Image in Question Conference, 3 August 2014. Sydney College of the Arts,University of Sydney. Retrieved September 13th, 2018, from http:/ / www.theimageinquestion.net/?page_id=20

Marassi, M. (1986). The hermeneutics of rhetoric in Heidegger. Philosophy and Rhetoric, 19(2), 79-98.

Marshall, D. L. (2017). Rhetorical trajectories from the early Heidegger,. Philosophy \& Rhetoric, 50(1), 50-72. doi:10.5325/philrhet.50.1.0050. 
Schrag, C. O. (1986). Communicative Praxis and the Space of Subjectivity. Bloomington: Indiana University Press.

Scult, A. (1999). Aristotle's rhetoric as ontology: A Heideggerian reading. Philosophy \& Rhetoric, 32(2), 146-159. Retrieved from https://doi.org/10.1353/par.2006.0001

Sheehan, T. (2005). Dasein. In H. L. Dreyfus, \& M. A. Wrathall (Eds.), A Companion to Heidegger (pp. 193-213). Malden:MA: Blackwell Publishing.

Sheehan, T. (2014). What, after all, was Heidegger about? Continental Philosophy Review, 47(3-4), 249-274. doi:https:/ / doi.org/10.1007/s11007-014-9302-4

\section{End notes}

i (A.I) There must exist an accepted conventional procedure having a certain conventional effect, that procedure to include the uttering of certain words by certain persons in certain circumstances, and further,

(A. 2) the particular persons and circumstances in a given case must be appropriate for the invocation of the particular procedure invoked.

(B. I) The procedure must be executed by all participants both correctly and

(B. 2) completely.

( Г.I) Where, as often, the procedure is designed for use by persons having certain thoughts or feelings, or for the inauguration of certain consequential conduct on the part of any participant, then a person participating in and so invoking the procedure must in fact have those thoughts or feelings, and the participants must intend so to conduct themselves, and further

(Г. 2) must actually so conduct themselves subsequently (see: Austin, 1994, pp. 14-15).

ii My analysis is inspired by Nikolas Kompridis's idea of 'enigma' in his reading of the film Blow-Up (Kompridis, 2014). 